\title{
Individual agency in contemporary academic life: The lived experience of internationalising the university curriculum in an increasingly competitive global marketplace.
}

\begin{abstract}
This article has two aims. First it highlights and affirms what is already known about the disposition of several western nation states towards a global education marketplace (Singh \& Doherty, 2004), the effects of globalisation upon the individual agency of university academics in education and performative education cultures (Lingard, 2010, Ball, 2006, Grek, 2009; Lingard \&, Rawolle, 2009, 2010). In particular, the article's context concerns the concepts of student recruitment and retention within an international program of study in a major university in Australia. Second, the article provides an analysis of a small amount of data to show that attempts by one university academic working within this program of study, to change and enhance the pedagogical value of the curriculum for students so that the university retains students, has to occur within an overarching and evaluative strategy measured in recruitment performance indicators expressed as numbers. This occurs to the detriment of a pedagogical and evaluative strategy that enhances the broader social agendas relating to the social and political significance of higher education qualifications. In stark terms, the article shows that evaluative measures adopted by this university quantify the university's growth in international reputation for research, ideas and the recruitment of educational experience, without seeming to quantify and qualify what that experience actually is. In the view of one university academic, performance (Garrick, 2006; 2010) through the provision of quality education programs in contemporary education systems seems simply a matter of saying that you have performed.
\end{abstract}

\section{INTRODUCTION}

This article seeks to capture the work undertaken by one university academic as they manage the intersection of three broad logistical parameters. First universities are drawn towards the global market place through the strategic provision of world class, internationally focussed degree programs. This involves the university in the recruitment of students from areas not usually serviced by that university. Luke et al. (2010) describe this function as a function of quality in terms of the world status of a university. Second, the university of the twenty- first century also exists within an environment where students increasingly travel to gain a better education or are the first in their families to seek higher education. The recruitment of a diverse range of students provides the equality agenda. Universities are engaged in the removal of barriers to participation in order for this to occur. Third, universities are increasingly accountable to provide evidence that they have been successful in this endeavour. Luke et al. refer to this agenda as that of control. This agenda is the performative education culture that binds these parameters together. This agenda seems to be 
the stronger agenda. This environment is influenced by the OECD, the United States of America and the World Bank (Wiseman, 2010) whose policy actors have engaged in a transnational push in the last two decades to quantify educational performance using measures that arise from the belief that knowledge is an abstract construct that is universal, containable and measurable. Empirical evidence in contemporary universities is considered the measure of how much is learnt, how many learn and how much is taught. In this sense, quality is defined as "how much" can be assessed summatively in order to gauge "how close" to excellence the student, lecturer, university, state and nation has come (Wiseman, 2010). The last measure provides both the goal of education in universities and the lever upon which funding, promotion and tenure are determined. Actions toward notions of perfect quality (Wiseman) taken by university administrators and policy actors to quantify, qualify and appraise the work of individuals have both a controlled and controlling element to them. These are evaluative measures written in performance indicators expressed as numbers.

This article investigates one university lecturer's management of these tensions as they operationalize a strategy of internationalising the curriculum for quality purposes within a broader strategy of control of the international recruitment and retention of students.

The data provided in this article are part of a larger data set from a longitudinal study that investigates the ways that lecturers in this program can make the content of their courses and their teaching more relevant and culturally appropriate for on and off shore students studying in the program. Changing the content of courses and changing teaching style is the way that lecturers in this program react to the three parameters that guide their work. This longitudinal study is quality and equality focussed through an examination of the control variables of what could make a difference to student learning and thereby what would make a difference to retention rates. The problem is that the now-commonplace and systemic performance indicators used to measure these variables are different from the experience of those involved in the project because they measure only what can be measured more generally and statistically. That is, the standard student evaluation of courses and course profile procedures adopted do not measure the intellectual labour and agency undertaken by academics in order to improve the experience of students in this program. What is measured and valued by this university's administrators is student achievement gains and teacher effectiveness expressed in what can be quantified. What is of interest here is the individual lecturer's agency within this policy process and their ability to make changes that can influence the broader strategy. The article seeks to answer one question namely:

How can an academic's individual agency in creating change be measured as they address policies concerning the quality and equality parameters of the internationalization of university programs in an increasingly controlled and controlling globalised marketplace.

There are three sub-questions embedded in this question namely:

1. Do performance indicators measure change in teaching style to manage the strategy and gain better retention rates;

2. Is this change-act actually relevant within the broader university culture of performativity in a global education market place? and

3. What is more important: the changes made to enact the internationalization strategy or their measurement? 
It seems that this may be a case where performance is for performance sake and the numbers so accumulated mean actually nothing.

The contemporary academic is now learning to react to the globalisation of the university market place and to the increasingly mobile nature of potential students within a numeric calculus adopted by universities to manage these changes. Contemporary thinking about universities and university policies involves the academic in thought about the best role of knowledge and for some, capital accumulation, especially within the current neoliberal turn of the enterprise university (Morrow \& Torres, 2000; Singh, Rizvi \& Shestha, 2007). It is the author's view that the internationalisation of curriculum content within university courses offered internationally is a far different premise than that of simply providing education to international students. The compositional and performative nature of the strategy, that " $x$ " amount of students need to be attending the university from countries other than Australia and that " $x$ " amount of international content be present in courses is different from actually engaging students in learning within these programs.

What follows is a discussion of the contexts in which universities work and in which one university academic works. First the discussion concerns the aims and objectives of university internationalisation strategies as a response to the global education marketplace. There is then a discussion of the recruitment and retention processes outlined in one university's internationalisation strategy. The recruitment goals of the strategy are then compared with retention strategies undertaken by one university academic for the purpose of improving teaching in a course of study at the university. The discussion therefore begins with the macro-developments in higher education and then filters down to the role of the individual academic in operationalizing these developments. This is undertaken to see if there is a synergy between the goals of the university, the goals of the academic and the goals of the performance indicators used to measure the success of the internationalization policy. From this, the article argues that definitions and experience of the quality and equality of an innovation such as internationalization can come to depend upon who is measuring and what is measured rather than on how and why something is measured.

\section{INTERNATIONALISATION STRATEGIES}

Universities have strategies of internationalisation in place to attract students. Because they are engaged in the market, these recruitment strategies are affected by the boom and bust cycles of monetary markets and they are affected by marketed reputation. The push and pull of globalisation and the neoliberal marketization of the university have been well documented (Peters, 1999; Smyth, 2000; Bagnall, 2002; Blackmore, 2003; Marginson \& van der Majik, 2006). In this environment universities have had problems finding a workable definition of internationalisation, a rationale for internationalisation and a workable approach to the articulation of policy into practice (Reid \& Loxton, 2004; Knight, 2004). It appears that policies of internationalisation are deeply contested.

In terms of finding a workable definition of internationalisation Knight (2004) believes that as the international dimension of higher education grows in importance those involved tend to use a definition of internationalisation in ways that best suit their purpose. In terms of the rationale that underpins a university's internationalisation definition and processes, Knight (2004) further claims that there has been great diversity of arguments in 
policy documents to account for the internationalisation of higher education. Knight maintains that these arguments often appear in policy documents as "overlapping rationales" (p.10). These overlapping rationales include both an economic and a political rationale alongside a cultural and educational rationale. De Vita (2003) however argues that the economic rationale predominates in the UK. Van Damme (2001) argues that this is also the case in Europe and Kelly (1999) affirms that the economic rationale for internationalising the curriculum in Australia also predominates. There are deep tensions here. Knight notes that contemporary universities are aspiring to implement a universality of knowledge in an environment where increasingly nation states have designs on them. Contemporary universities are attempting to care for individuals who desire a less parochial, more universal approach to their learning, research and future careers thereby embracing intercultural understandings and development. This is juxtaposed against the nation state's view that education leads to technological development and innovation and then economic growth. In the economic and political rationale it is hoped that individuals so trained will be the decision makers of the future, invested with their home and host country's moral, cultural and political values. This, proponents of the economic and political rationale believe will benefit the host country politically and internationally. Definitions and rationales for internationalisation have effects on the process of internationalisation and this is now discussed in relation to one Australian university.

\section{ONE UNIVERSITY'S INTERNATIONALISATION STRATEGY}

The internationalisation strategy of this university defines internationalisation to be a "process of integrating an international, intercultural or global dimension into the purpose, functions or delivery of post- secondary education" (University Internationalisation Strategy, 2007, p.1). The internationalisation strategy is framed within the context of the University's Mission Statement, Strategic Plan 2006-2010, University 2015, Learning for Success (Academic Plan 3) 2008-2010 and the University Research Plan 2005-2010.

Particularly, the University's Mission Statement outlines the goals of the university to include:

In the pursuit of excellence in teaching and research, the University is committed to:

- Innovation

- Bringing disciplines together

- Internationalisation (my emphasis)

- Equity and social justice, and

- Lifelong learning.

for the enrichment of Queensland, Australia and the international community (p.1).

The university has in place several processes that map and evaluate the effect of the strategy in both on and off shore campuses, for academics and research and for course work. The evaluative measures for student recruitment seem to be more valued in the strategy than evaluative measures concerning the effective retention of students. 


\section{RECRUITMENT}

The performance indicators of most relevance to the recruitment of students into international course work programs at this university include the:

- Number of students coming to the university on scholarships (domestic and international)

- Numbers of countries from which the university's international student body is drawn

- Spread of international student load across academic groups, programs and campuses

- Achievement of student load targets in the University's Strategic Plan

The university's Strategic Plan 2006-2010 sets targets, where at least $25 \%$ of the current student body is comprised of international students. This theme is reiterated for the 2015 Strategic Plan. The strategy very clearly sits within a global and marketised quality and equality agenda.

The Internationalisation Strategy (2007) then has the following accountability framework for this recruitment to occur:

- Development of recruitment plans and exchange agreements - PVC (I), Group PVCs

- Provision of scholarship support - DVC (R), Group PVCs

- Development and support of links with scholarship bodies - PVC (I)

- Provision of reports monitoring recruitment of students by Group, program and campus

- Director, QPS, PVC (I).

These accountabilities pass down to faculties and then on to Program Convenors who are responsible for the Annual Program Review and Improvement Report for each program and they also monitor the course profiles for each course in the program. This is the agenda of control of the marketplace initiatives. Individual academics are then held accountable through the Student Evaluation of Course and the Student Evaluation of Teacher mechanisms in place to determine the effectiveness of teaching in all courses in degree programs.

Within the broader internationalisation strategy, the education faculty of this university actively markets to students in Canada and parts of South East Asia. The product sold by this faculty is a Master's level program in education that is a two year degree where students undertake a course of study similar to, but not exactly the same as, the Graduate Diploma's program structure that is offered to local students. International students attend the campus for 18 months and then undertake an additional internship program that can be completed in either home or host countries. Students are expected to complete a thesis subject. This Master of Teaching program is guided by local and international teacher registration and certification procedures and the curriculum is approved internationally and in Australia. 
In this degree program, recruitment plans are in place to maintain market share. There are scholarships available to international students interested in the program and these are carefully monitored and a committee monitors the rate of take-up for courses. This committee is also actively involved in recruitment procedures in overseas markets. The performance indicators for recruitment seem effective in examining each of these factors and these inform the work undertaken within this degree program.

\section{RETENTION}

The situation is a little different for the measurement of retention rates however. It is here that it is possible to see the tension for university academics when working in this program. In relation to the retention of students once recruited in this university's degree programs the Internationalisation Strategy (2007) provides a number of relevant performance indicators, namely the:

- Extent to which programs and courses include international content and themes,

- Extent to which programs and course planning takes account of high international student demand in the global environment

- Retention and progression rates of international students

- International graduates in leadership positions in Australia or elsewhere

- Graduate employment rates in Graduate Destination Survey as reported by the Graduate Careers Council of Australia

In all cases the accountability for maintaining the performance lies with the Pro ViceChancellor and Deans of Teaching and Learning through Learning and Teaching Committees. However, the indicators for recruitment are measured in numbers and those for retention are measured by "the extent to which programs and courses include international content and themes". These indicators are qualitatively different from the recruitment indicators and it is here that some tensions arise.

The internationalisation strategy of this university defines internationalisation to be a "process of integrating an international, intercultural or global dimension into the purpose, functions or delivery of post- secondary education" (University Internationalisation Strategy, 2007, p.1). Lecturers and students retained in programs and courses at this university are affected by this definition. There are at least four mechanisms for checking the effectiveness of internationalisation processes, practices and procedures. These mechanisms include graduate attribute statements, the course profile system, the Annual Program Review and Improvement Report system and the Student Evaluation of Course and the Student Evaluation of Teacher mechanisms.

First, a set of graduate attributes give expression to the University's intent to equip its graduates for work in an international, multicultural and multilingual environment. This is particularly described in Graduate Attribute Number Five where the university aims for students to be competent in culturally diverse and international environments. These graduate attributes are listed and explored in every course profile produced by the university.

Second, performance is also measured within and through the university's course profile system where academics are provided with the following statement: 
This section [of the course profile] has been designed to determine the extent to which your course contains internationalisation specific learning experiences that aim to develop respect, awareness, knowledge and skills to interact effectively in culturally or linguistically diverse contexts, and/or contain global and international perspectives in a discipline (University Course Profile Handbook, 2011).

When preparing course profiles course convenors are asked to tick a box if they include international perspectives in their courses, whether or not their course provides for an overseas exchange or experience, and whether or not the course includes activities that foster intercultural awareness or the study of a foreign language. Course convenors are asked to list any other internationalisation and cultural diversity objectives in detail. Course convenors are also asked to indicate by ticking a box if they have not included international content, practices and procedures.

The third mechanism to assess progress in internationalising the curriculum is the Annual Program Review and Improvement Reports of the university. These are derived from exit surveys of student satisfaction. These program reviews consider performance items such as numbers of students studying, their retention rates and completion, their success in postgraduation employment and further study and graduate perceptions of satisfaction with the program, graduate skills and good teaching.

The fourth measurement concerns the ability for academics to include a question about their effectiveness in implementing international content in their courses in the Student Evaluation of Course and the Student Evaluation of Teacher mechanisms. These evaluations contain standardised questions about course and teacher effectiveness that are developed at the system level. These standardised questions do not include questions related to internationalising the curriculum. Individual academics can add these questions, but rarely do given that anecdotal evidence suggests that students are overloaded with the process of evaluation already.

There is not a system-wide and strategically focussed performance measure for internationalising the curriculum within this University's Internationalisation Strategy (2007) that directly relates to an individual academic's performance of internationalisation as a lecturer in this field on a day to day basis; nor should there be.

\section{RECRUITMENT AND RETENTION COMBINED: The role of the individual academic.}

The intersection of recruitment and retention issues for academics was studied through data taken from a longitudinal study of the course content of courses provided in the Master of Teaching international program. The study is entitled Transformative pedagogy: The use of narrative and the Great Aussie yarn to improve the international component of a course of study in education. This study was undertaken for the purpose of improving the content of the degree program's courses and to make teaching more relevant and culturally appropriate for on and off shore students studying in the program. The study aimed to improve the experience of students retained in this degree program and could be said to be quality and equality focussed using Luke et al's. (2010) understanding of these terms. Two data sources 
are relevant, namely the course content for the years 2008 and 2010 and the evaluative tools chosen by the university to measure the degree of internationalisation.

\section{Description of the study}

The study began with one course convenor in the Masters of Teaching program described previously. For the duration of the study, namely the period from 2008 to the present, the course convenor went from lecturer in the program to Program Convenor. What follows is an account of their change trajectory because of this involvement.

In 2008 the course convenor had not read the internationalisation strategy nor known about it. On the contrary, the title of the study originated in the anecdotal feedback for one course in the program in 2008. In this sense the "extent to which programs and courses include international content and themes" was not a question in a standard set of questions in an evaluative tool. Rather, students raised the issue in a forum for that purpose held by another lecturer who received poor ratings in the Student Evaluation of Course and the Student Evaluation of Teacher data. Students from Canada and South East Asia expressed concern that their lecturers "told too many stories". They also expressed some anger that they had been recruited into a program of study that appeared not to be catering for their unique needs as they saw them. This comment became a topic of discussion in the school with individual lecturers expressing that they had received similar comments and the "unofficial consensus" about the comment came to mean that students in the program were used to a more factually oriented lecture program. That is, the collective belief about the comment was that lectures should just contain the facts without storied embellishment. Because Student Evaluation of Course and the Student Evaluation of Teacher data for 2008 seemed to be universally low across the program, issues of retention of recruited students were paramount.

From this, the course convenor decided to explore the matter of narrative and learning further. In late 2008 and early 2009 this lecturer changed their lecture style, not to increase the number of facts, but to explain the use of narrative or stories in teachers' work. The lecturer deliberately sourced the work of narrative writers from Singapore and Canada who explained teachers work in the context of story. In this, there was a clear choice. The work of the Canadian based Jean Clandinin was particularly useful. The lecturer drew on the writing of Allan Luke, who is an Australian of British Columbian origins; Peter Freebody, an Australian who with Allan Luke had worked with the Singaporean education system to create change; Joann Phillion a lecturer from Canada who is involved in narrative inquiry into teachers work and Lisa Patel Stevens who is an American writer in the field of study covered by the course in question. A snapshot of the course content is provided in Table One: Weekly topics for a course in an International Masters of Teaching degree (2008) and Table Two: Weekly topics for the same course in an International Masters of Teaching degree (2010).

INSERT Table One: Weekly topics for a course in an International Masters of Teaching degree (2008) HERE.

INSERT Table Two: Weekly topics for the same course in an International Masters of Teaching degree (2010) HERE.

The content of both the 2008 and 2010 course examined the middle schooling movement and the teaching and learning needs of students in the middle years of schooling. This course 
was a key course in the Masters of Teaching Secondary program offered at this university. However, in the lecture content list provided for 2008 there was no mention of any country's middle schooling experience other than that of Australia. Even more parochially there were references to the Queensland scene and the text used was a text written by Pendergast \&Bahr (2005) entitled Teaching Middle Years: Rethinking curriculum, pedagogy and assessment. This is a local text albeit with international significance. The text was changed in 2010 to include drafts of a more recent version of Teaching Middle Years: Rethinking curriculum, pedagogy and assessment (2010) that now has an expressed internationally explicit focus. The voices of individual and internationally renowned researchers were added to the Australian content of the course so that comments such as those expressed anecdotally, did not occur again.

As a consequence of these changes to curriculum content and approach, in 2010 the following comments were made on the Student Evaluation of Course and the Student Evaluation of Teacher for this lecturer:

- Great inclusion of life experiences into lecturing and tutorial leading.

- [The lecturer] is well versed and knowledgeable in both her subject area and her real world experience. She "kept it real" even while teaching some very academic and theoretical concepts.

- I liked the concept that she introduced at the beginning, about using her "story". She used this the whole way through, as she told us of her experiences and situations and this really brought home the meaning of what she was teaching to us. This was quite an interesting class.

- Personal narratives and real instances and examples from the class room.

- One of the greatest lecturers I've had in my six years at University. She provided real world experience and applied that experience into the teaching(s) of the course.

These comments were vastly different from the anecdotal comments of 2008. Indeed the course convenor's overall approval rating as expressed in the Student Evaluation of Course and the Student Evaluation of Teacher data was 4.67 in 2008, but 5.3 in 2010 and the approval rate for the lecturer's effectiveness was 5.6 in 2008 and 5.9 in 2010 all on a 6 point scale.

It is important to note that the changes to the data between 2008 and 2010 were not the result of the influence of the 2008 anecdotal comments alone. They were the result of a confluence of "thinking through" the three parameters discussed above; namely the drive for quality, equality and control of the processes of internationalising the curriculum. Here the university academic exercised some agency. Characteristics and circumstances unique to this lecturer's career trajectory coalesced into action and agency for the lecturer. By 2010 the lecturer had some control over the delivery of international content. They no longer inherited a course already designed, but instead made changes to the design so that international content was included and foregrounded. The lecturer moved away from purely Australian content so as to include students from other cultures in a more meaningful way (Bell, 2004; Singh \& Doherty, 2004). The lecturer argued that they felt more comfortable with the subject matter of the course, in their role as an academic and in their role as Program Convenor of the Master of Teaching (Secondary) program. By 2010 the lecturer had been given managerial 
responsibility of the cohort of students from Canada, which included Canadian students of African and South East Asian heritage. Their role expanded to the management of their experience within the school and within their home and host countries. By 2010 the lecturer had finally read the internationalisation strategy. In this position they could see the benefit of uniting recruitment with quality lectures that considered equality through retention.

The lecturer also expressed in interview that they had a disposition towards inclusive education practices rather than in exclusive practices and was comfortable with the definition of internationalisation provided by the university, namely that internationalisation is the "process of integrating an international, intercultural or global dimension into the purpose, functions or delivery of post- secondary education" (University Internationalisation Strategy, 2007, p.1).

In 2011 the longitudinal study has shifted to include all lecturers in the Master of Teaching program and a survey of all staff and students has been designed to ask more detailed questions about student and teacher assumptions about learning in the program.

\section{BY WHAT MEASURE WAS THE LECTURER SUCCESSFUL?}

In this section I discuss the changes made by one university academic to improve both the retention of students in the program and then by extrapolation the recruitment of students in the program. The point is made that the academic's work is not reflected in the data gathering procedures that surround the program at the institutional level and thus institutionally they are irrelevant.

The longitudinal study is in its infancy, but already asks more questions than it answers. The number of lecturers and students involved in the study has grown. But, who owns the progress made in the course discussed in this article? Does ownership come down to the anecdotal comments that caused one lecturer to inquire further and talk to their colleagues about this? If so then the importance of talking to one's students and colleagues seems to outweigh the reading of Student Evaluation of Course and the Student Evaluation of Teacher data. This "talk" is not measured and seems not to be valued by the university. Does the lecturer who made changes own the success? If so, how is that agency measured in any meaningful way by the university and how is that agency captured for others to share? Was it the lecturer's interventions that made changes or was it just a matter of doing their job in a manner that was inclusive of those who felt excluded? These questions go to the heart of the earlier question raised in this article namely;

How can an academic's individual agency in creating change be measured as they address policies concerning the quality and equality parameters of the internationalization of university programs in an increasingly controlled and controlling globalised marketplace. 
The Student Evaluation of Course and the Student Evaluation of Teacher data over time definitely show that students were happier with the course they were provided. The performance of the internationalised curriculum for this period was also measured in the Annual Program Review and Improvement Reports of the university. This tool draws on exit surveys of student satisfaction that consider performance items such as numbers of students studying, their retention rates and completion, their success in post- graduation employment and further study and graduate perceptions of satisfaction with the program, graduate skills and good teaching. In all but the student numbers indicator the Master of Teaching (Secondary) program excelled with student satisfaction with the program growing from around $30 \%$ in 2008 to $100 \%$ in 2010 . In relation to the student numbers indicator this university's market was affected by the global financial crisis and the rise in the Australian dollar.

What is important here is the question as to who can claim this success. The data expressed as numbers do not show the intellectual and physical labour undertaken to improve student performance and satisfaction with one course. In terms of the numeric, and/or tick a box evaluative tools, the lecturer cannot claim that they had anything to do with improvements made towards internationalising the curriculum. The numeric statistics seem to mean nothing in relation to the lecturer involved. From the numbers it is impossible to discern if any particular practice has helped in the student satisfaction ratings. Yet this is the measure cited in the strategy as an indicator that the strategy has been successful. Another lecturer in a completely different degree program who meets the standardised questions asked in the Student Evaluation of Course and the Student Evaluation of Teacher data at the same standard as the lecturer described here could gain this rating without having any international content in their degree and course programs or without the same amount of intellectual labour. The textual data drawn from the evaluative tools show improvement in the extent to which programs and courses include international content and themes, take account of high international student demand in the global environment and the extent of retention and progression rates of international students. But the numerical data expressed in the course profiles, the annual review statements and the numbers from the teaching and course evaluations are empty of the human processes of teaching.

Vongolis-Macrow (2005) defines this human process as a self and others process affected by the involvement of educators in a globalised world. This world when expressed as numbers seems to excise educators from traditional sites of agency or at the least does not account for the "talk" that occurred following the release of numeric data studied in this article. In the past educators gained agency through their sense of obligation to pedagogy, curriculum, social justice and community (Vongolis-Macrow). Although the lecturer exercised individual agency within their course of study, the overarching reform that now drives the knowledge economy and global economic restructuring of education seems not to call upon nor seem to value educators' expertise in knowledge, learning and pedagogy.

\section{A QUALITY EDUCATION}

This places the definition of a quality university education within a globalised world in focus. Universities are in the business of providing a quality education product to a much wider audience than heretofore. Luke et al., (2010) observe that students who were previously referred to as non- mainstream and minority populations are frequently the norm in schools 
and universities now, rather than the exception and these communities have powerfully articulated rights where they once stood on the margins. That is, it is in a university's best interests to account for diversity in the quality provision of its courses. Quality though is a contested term that depends upon who determines the concept's characteristics and factors. In the discussion provided it is clear that a group of students exercised their rights to complain about the quality of education they were receiving. It is clear that lecturers in the program have begun to answer those complaints and to account for equality in their degree programs. But what is measured as quality seems not to account for this intervention. A number of theories provide a lens on this contestation. Theories of post-structuralism, neo-structuralism and super-structuralism, late capitalism and capitalist globalisation each articulate a vision of contemporary times. From the small amount of data provided in this article it appears that the adoption of neo-structuralist principles in order for capitalist globalisation to occur are resurgent and hegemonic.

The concept of quality in relation to universities and their product draws on a number of theories where the form and function of universities can be variously described. Poststructuralist theorists (Chouliaraki \& Fairclough, 1999; Young, 1999, 2007; Giddens, 1991; Hier, 2003; Hey, 2002), emphasise the belief that we live in a new era that is different from the grand ideas and narratives of the past. Within this theory we are each advised that we cannot hold onto or define easily that which occurs around us. Within this paradigm and against grand narratives there is a yearning for the small narrative of lived experience, for the diverse and complex intuition and experience that occurs through experience (Smith, 1990). In relation to the concept of quality then, for those who ascribe to this view, there can be no overarching definition of quality as it concerns the multiple definitional options available to take up. That is, there is no grand definition of quality. This of course contests with the structure imposed on universities by performance indicator measures of quality and somewhere at this intersection the university academic struggles between the grand and the small. The provision of the small amount of textual data in this article is juxtaposed against an entire system of numeric data used by the larger narrative of performance indicators.

The concept of quality in relation to universities and their product can also be defined using variations of the word structuralism such as "super-structuralism" and "neostructuralism" (Peters, 2001, p.2) to capture the intellectual thought as to whether or not we have in fact moved beyond structuralism. Structuralism is defined by Turner \& Abercrombie (2000) to mean that society is prior to the individual and that structures determine how the individual is to perform. This conundrum is evident in this article because of the structures now imposed on universities by the perceived rigour of performance and evidence based policy indicators. The public face of such policy is that quality university education is governed by and able to be assessed through "how much" indicators expressed as numbers. There can be a discrepancy between an individual academic's experience of the structured environments in which they work and the emerging agency of their own pedagogical practice. This discrepancy may well be accounted for by the fact that we have not changed and that structures still bind us.

Universities also exist in an era of late capitalism (Blim, 2000), or late capitalisms (Garrick, 2010) within an era of capitalist globalisation (Jameson, 1993; Waldby \& Mitchell, 2006, McLaren \& Farahmandpur, 1999; Luke, 2004; Lingard, 2000; Cullen, 2005; Gulson, 2007; Sklair, 2006). Late capitalism defines the current market as one where there is a purer and more prodigious form of capital that is finely honed and tuned into areas of our current lives that have previously defied commodification (Jameson, 1993). We may not have been so 
concerned about internationalising the curriculum were it not for the transnational movement of global capital exemplified here by the movement of individuals to gain a better education. This transnational movement provides the stock and trade of university internationalisation strategies/policies. The policies available for take-up within universities have been severely limited by the influence of OECD (Larsen, Martin \& Morris, 2002) indicators and by the hold that neoliberal principles have had on education for a good while (Harvey, 2005). Universities are now part of this transnational movement of capital and movement of a transnational capitalist class. In 2008 for example this university accepted over 300 applications for the Masters of Teaching program, but by 2010/2011 the numbers had dropped to under 50 students. Here, the university's staffing, program structures and budgets are implicated within what Gibson and Graham (1998, p.9) refer to as "the international space of the pure economy, an enormous monetary mass, coextensive with the social field, a worldwide axiomatic or the relentless saturation of any remaining voids and empty places, appropriating individuals to its circuits". There are many capitalism $(s)$ (Garrick, 2010) that have made up this discursive field. These constructs have material effects (Quiggin, 2010).

Quality in the sense of these theories is determined by "how well" or "how near to perfect" (Wiseman, 2010) a university achieves the marketization of their university's reputation through a product that is marketed to a world audience. In the case of this article that product is an internationalisation strategy providing internationally strong university qualifications. Even when the product is reputation, somewhere and somehow, individuals enter into a contract to accept or not accept the reputation on offer. When students are encouraged to come to a university that is not in their home country, then money is added to the contract and the current rules of the market then apply. Students in the degree program described in this article accepted the marketed reputation of the degree and so were recruited. But for them, retention in the degree was more important than signing up for the degree. They had some agency in this market. It was not market forces though that aided them, but teacher practice within a "self and others" (Vongolis-Macrow, 2005) environment.

Luke (2010), Lingard (2010), Ball (2006), Grek (2009) and Lingard \& Rawolle ( 2009, 2010) each affirm the performative turn of education in the late twentieth early twenty first centuries toward statistical measurement of success. Such statistical measurement of education programs has been made easier through changes in technology and the ability to capture and store huge amounts of data. There is also the impact of the evidence based policy movement of the first decade of this century where policy that could be measured and easily accessed for future policy implementation was valorised (Boaz, Ashby \& Young, 2002). These are all structural changes. Steiner-Khamsi (2004) asserts however that such policy is adopted because it is measurable and easily accessible, and not because it is necessarily helpful. Here the OECD has had a role to play as a policy actor that has carved out an authority to act based upon the organisation's perceived technical competency in the development of educational indicators and comparative educational performance (Grek, 2009).

\section{CONCLUSION}


This article has addressed the question as to whether or not an academic's individual agency in creating change that addresses policies of the internationalization of university programs in an increasingly globalised marketplace has any performative outcome in terms of the internationalisation policy and its measurement. The discussion suggests that the evaluative tools used to measure the successful retention of students within an international degree suit an economic calculus more than they suit any meaningful pedagogical calculus. Stated simply, the university can quantify their role in the global education market place without necessarily qualifying what that role is. However, changing the indicators of retention from "the extent to which" to numeric indicators is not a solution that can be drawn from the data provided here. Rather, this article has talked about pedagogical practices that have made a difference. These practices need to be extended in order to protect the agency that individual lecturers and students can exercise within the performative turn of education in the early twenty first century toward the statistical measurement of success.

\section{REFERENCES}

Bagnall, R. (2002). The contingent university: An ethical critique. Educational philosophy and theory.34(1).77-90.

Ball, S. J.(2006). Education policy and social class: The selected works of Stephen Ball, 4353. London: RoutledgeFalmer.

Ball, S. ( 2009). Privatising education, privatising education policy, privatising educational research: network governance and the 'competition state'. Journal of Education Policy. 24(1). $83-99$.

Bell, M. (2004). Internationalising the higher education curriculum - Do academics agree? Research and Development in Higher Education. Retrieved from http://www.herdsa.org.au/wp-content/uploads/conference/2004/PDF/P036-jt.pdf. January 162010.

Blackmore, J. (2005). 'The emperor has no clothes': professionalism, performativity and educational leadership in high-risk postmodern times. Leadership, gender and culture in education: male and female perspectives. Maidenhead England: Open University Press.173-194.

Blim, M. (2000). Capitalisms in late modernity. Annual Review of Anthropology.

Boaz, A., Ashby, D. \& Young,K. (2002). Systematic Reviews: What have they got to offer evidence based policy and practice? ESRC UK Centre for Evidence Based Policy and Practice. Queen Mary. University of London. 
Burbules, N. \& Torres, C. (2000). Globalization and education: Critical perspectives. New York: Routledge.

Chouliarki, L. \& Fairclough, N. (1999). Discourse in Late Modernity: Rethinking Critical Discourse Analysis, Edinburgh: Edinburgh University Press.

Cullen, D. (2005). Globalisation and pre-service teacher education in Australia: A new dimension. International handbook on globalisation, education and policy research. Part One. 315-326.

De Vita, G. (2003). Rethinking the internationalisation agenda in UK higher education Journal of Further and Higher Education.27(4).383-398.

Garrick, B. (2006). The Stuff of Knowledge in schools. Welcome to the Desert of the Real. International Journal of the Humanities, 4(3). 111-118.

Garrick, B. (2010). Learning how we are led at the edge of the day: An evaluation of neoliberal school based reform in the late twentieth and early twenty first centuries. Lambert Publishing. Saarbrucken: Germany.

Gibson, J., \& Graham, K. (1998). Beyond patriarchy and capitalism: Reflections on political subjectivity. In B. Caine \& R. Pringle (Eds.), Transitions: New Australian feminisms (pp. 172-184). St Leonards, NSW: Allen \& Unwin.

Giddens, A. (1991). Modernity and self-identity: Self and society in the late modern age. Stanford: Stanford University Press.

Grek, S. (2009).Governing by numbers: the PISA 'effect' in Europe. Journal of Education Policy, 24(1), pp. 23-37.

Gulson, K.N. (2007). Mobilising space discourses: Politics and educational policy change. In K.N. Gulson \& C. Symes (eds). Spatial theories of education: policy and geography matters. New York: Routledge.

Gulson, K.N. \& Symes, C. (eds). Spatial theories of education: policy and geography matters. New York: Routledge.

Harvey, D. (2005). A brief history of neoliberalism. London: Oxford University Press.

Hewison, A. (2008). Evidence-Based Policy. Policy, Politics \& Nursing Practice. 9(4). 288298.

Hey, E. (2002). Introduction - Globalisation and International Law. International Law

Forum. Netherlands: Kluwer Law International. 
Hier, S. P. (2003). Risk and panic in late modernity: Implications of the converging sites of social anxiety. The British Journal of Sociology. 54(1). I3-20.

Jameson, F. (1993). Postmodernism or the cultural logic of late capitalism. Docherty, T. (Ed.). Postmodernism: A reader. (pp. 62-92). Hemel Hempstead, UK: Wheatsheaf.

Kelly, P.F. (1999). The geographies and politics of globalization. Progress in human geography. 23(3).379-400.

Knight, J. (2004). Internationalization Remodeled: Definition, Approaches, and Rationales. Journal of Studies in international education. 8(1). 5-31.

Larsen, K., Martin, J.P. \& Morris, R. (2002). Trade in educational services: trends and emerging issues. The world economy. 25(6). 849-868.

Lingard, B. (2000). Federalism in schooling since the Karmel Report (1973). Schools in Australia: From modernist hope to postmodernist performativity. The Australian Educational Researcher, 27(2), 25-63.

Lingard, B. (2010). Policy Borrowing, Policy Learning: Testing Times in Australian Schooling. Critical Studies in Education, 51(2). 129-147.

Lingard, B., \& Rawolle, S. (2009). Rescaling and reconstituting education policy: The knowledge economy and the scalar politics of global fields. In M. Simmons, M. Olssen \& M. Peters (Eds.), Rereading education policies: Studying the policy agenda of the twenty-first century. Rotterdam: Sense Publishers.

Lingard, B., \& Rawolle, S. (2010). Globalization and the rescaling of education politics and policy: Implications for comparative education. In M. Larsen (Ed.), New thinking in comparative education: Honouring the work of Dr Robert Cowen. Rotterdam: Sense Publishers.

Luke, A. (2004). Teaching after the market: From commodity to cosmopolitan. Teachers College Record, 106(7), 1422-1443.

Luke, A., Green, J. \& Kelly G. J. (Eds.) (2010). What counts as evidence in educational settings? Rethinking equity, diversity, and reform in the 21st Century. Review of Research in Education, 34.

McLaren, P., \& Farahmandpur, R. (1999a). Critical multiculturalism and globalization: Some implications for a politics of resistance. Journal of Curriculum Theorizing. 15(3), 2746.

Marginson, S. \& van der Marijk, W. (2006). Globalisation and higher education. Center for Higher Education Policy Studies. External report OECD.

Morrow, R. \& Torres, C. (2000). The state, globalization and education policy. In N.Burbules \& C. Torres (eds). Globalization and education: Critical perspectives. New York: Routledge. 
Pawson, R. (2002). Evidence based policy: The promise of realist synthesis. Evaluation. 8(3).340-358.

Pendergast, D. \& Bahr, N. (Eds.). (2005). Teaching middle years: rethinking curriculum, pedagogy and assessment $1^{\text {st }}$.ed. Crows Nest: Allen and Unwin

Pendergast, D. \& Bahr, N. (Eds.). (2010). Teaching middle years: rethinking curriculum, pedagogy and assessment 2nd.ed. Crows Nest: Allen and Unwin.

Peters, M. (1999). Globalisation and the crisis in the concept of the modern university. Australian Universities Review. Palmerston North, New Zealand: Dunmore Press.

Peters, M. (2001). Poststructuralism, Marxism and neoliberalism.Boulder, Calif: Rowman and Littlefield.

Phillips, D. (2000). Learning from elsewhere in education: Some perennial problems revisited with reference to British interest in Germany. Comparative Education, 36(3), pp. 297307.

Quiggan, J. (2010). Zombie economics: How dead ideas still walk among us. Princeton, New Jersey: Princeton University Press.

Reid, A. \& Loxton, J. (2004). Internationalisation as a way of thinking about curriculum development and quality. Proceedings of the Australian Universities quality forum: AUQA Occasional Publication.

Singh P, \& Doherty, C. (2004). Global cultural flows and pedagogic dilemmas: teaching in the global university contact zone. TESOL Quarterly 38.9-42.

Singh, M., Rizvi, F. \& Shrestha, M. (2007). Student mobility and the spatial production of cosmopolitan identities. In K.N.Gulson \& C. Symes (Eds). Spatial theories of education: Policy and geography matters. New York: Routledge.

Sklair, L. (2000). The transnational capitalist class and the discourse of globalisation. Cambridge Review of International Affairs. Cambridge: Routledge

Smith, D. (1990). The everyday world as problematic. Boston: North Eastern Press.

Steiner-Khamsi, G. (Ed.). (2004). The global politics of educational borrowing and lending. New York: Teachers' College Press.

Turner, B. \& Abercrombie, N. (2000). The Penguin dictionary of sociology. London: Penguin.

Van Damme, D.V. (2001). Quality issues in the internationalisation of higher education. Higher education.41(4).415-441.

Vongolis-Macrow, A. (2005, November). I, Teacher: agency in globalised education. Paper presented at the Australian Association for Research in Education Annual Conference, Parramatta, NSW. 
Waldby, C. \& Mitchell, R. (2006). Tissue Economies: Blood, Organs and Cell Lines in Late Capitalism Duke: UP.

Wiseman, A. W. (2010). The uses of evidence for educational policymaking: Global contexts and international trends. In A. Luke, J. Green, \& G. J. Kelly (Eds.), What counts as evidence in educational settings? Rethinking equity, diversity, and reform in the 21st Century. Review of Research in Education, 34.

Young, M. (1999). Rethinking teacher education for a global future: Lessons from the English. Journal of Education for Teaching, 24(1), 51-62. 
Table One: Weekly topics for a course in an International Masters of Teaching degree (2008)

\begin{tabular}{|c|c|c|}
\hline 1 & Topic & Content \\
\hline 1 & $\begin{array}{l}\text { Middle Years of } \\
\text { Schooling: What's it all } \\
\text { about? }\end{array}$ & $\begin{array}{ll} & \text { Course Overview } \\
-\quad & \text { Expectations, responsibilities, communication } \\
\text { - } & \text { Theoretical and historical background } \\
& \text { How do different schools participate in middle schooling? }\end{array}$ \\
\hline 2 & $\begin{array}{l}\text { Who are Middle Years } \\
\text { of Schooling students? }\end{array}$ & $\begin{array}{l}\text { - Who are the young people in their middle years of schooling? } \\
\text { - How are they understood as learners in schools as sites for learning? } \\
\text { - With what issues and contexts must they deal? } \\
\text { - What resources can they access? } \\
\text { - How can they be and not be? } \\
\text { - What does school mean to them? }\end{array}$ \\
\hline 3 & $\begin{array}{l}\text { Curriculum Practices in } \\
\text { the Middle Years of } \\
\text { Schooling. }\end{array}$ & $\begin{array}{ll} & \text { What is curriculum? } \\
\text { - } \quad \text { Types of curriculum (integrated, negotiated, etc) } \\
\text { - How and by whom might curriculum be constructed? } \\
\text { - } \quad \text { How can curriculum be engaging for those participating in it? } \\
\text { - What are the relationships between curriculum, pedagogy and assessment? }\end{array}$ \\
\hline 4 & $\begin{array}{l}\text { Pedagogical practices } \\
\text { in the middle years of } \\
\text { schooling. }\end{array}$ & $\begin{array}{l}\text { - What is pedagogy and what choices are needed to work towards particular ways } \\
\text { of learning for the middle years? } \\
\text { - What part do teachers play in pedagogies? } \\
\text { - What are the different pedagogies used? } \\
\text { - Which pedagogies best fit particular contexts and outcomes? } \\
\text { - What are the productive pedagogies (QRSLS) }\end{array}$ \\
\hline 5 & $\begin{array}{l}\text { Assessment practices } \\
\text { in the Middle Years of } \\
\text { Schooling }\end{array}$ & $\begin{array}{ll} & \text { Assessment in the middle school: What it is and what it is not. } \\
\text { - } & \text { Why, who, how and when do we assess? } \\
\text { - } & \text { Authentic assessment, portfolios, peer and self-assessment } \\
\text { - } & \text { Relationship between planning, curriculum, pedagogy and assessment } \\
\text { - Current systemic assessment reforms }\end{array}$ \\
\hline 6 & $\begin{array}{l}\text { Organisational } \\
\text { Practices in the Middle } \\
\text { Years of Schooling }\end{array}$ & $\begin{array}{l}\text { - How do the organisational practices proposed in the Middle Phase of Learning } \\
\text { Action Plan support learning and teaching in the middle years? }\end{array}$ \\
\hline $7,8,9$ & Assessment Block & Week 7 Exam \\
\hline ks & cticum & \\
\hline
\end{tabular}


Table Two: Weekly topics for the same course in an International Masters of Teaching degree (2010) 


\begin{tabular}{|c|c|c|}
\hline Lectures & Readings & Tutorial Activities \\
\hline $\begin{array}{l}\text { Theme 1: The place of } \\
\text { Middle Years of } \\
\text { Schooling: } \\
\text { Chief theorists } \\
\text { Major narratives } \\
\text { Theoretical and historical } \\
\text { background } \\
\text { WEEK ONE }\end{array}$ & $\begin{array}{l}\text { Focus on the context of the MYS reforms and a sense of place for the reforms: } \\
\text { I have chosen to use a narrative focus to show you that there are now many stories } \\
\text { about the MYS schooling. There is the international and national story, MYSA's story } \\
\text { and the stories in these readings. For the exam you will have to be familiar with these } \\
\text { story lines and be able to write an essay/s explaining the stories with the view to } \\
\text { explaining why narratives in teaching are important. So: } \\
\text { - Download and read the ETRF policy. You can obtain this from the course website } \\
\text { at L@G. Read the P-12 Curriculum Framework. } \\
\text { - Read Rust, F. C. (2002).Professional Conversations: new teachers explore } \\
\text { teaching through conversation, story and narrative. In N.Lyons, V. Kubler La } \\
\text { Boskey. Eds.) Narrative inquiry in practice: Advancing the knowledge of } \\
\text { teaching,Teachers College Press: Columbia.pp173-189. } \\
\text { Read one other of the suggested readings } \\
\text { Johnson, K.E. and Golombek, P.R. (2002). Teachers narrative inquiry as } \\
\text { professional development. Cambridge: Cambridge University Press. } \\
\text { Phillion, J. A. (2002). A story of becoming a narrative inquirer in a multicultural } \\
\text { landscape. Narrative inquiry in a multi-cultural landscape: multicultural teaching } \\
\text { and learning. Greenwood Publishing group: Westport, CT. 105-107. }\end{array}$ & 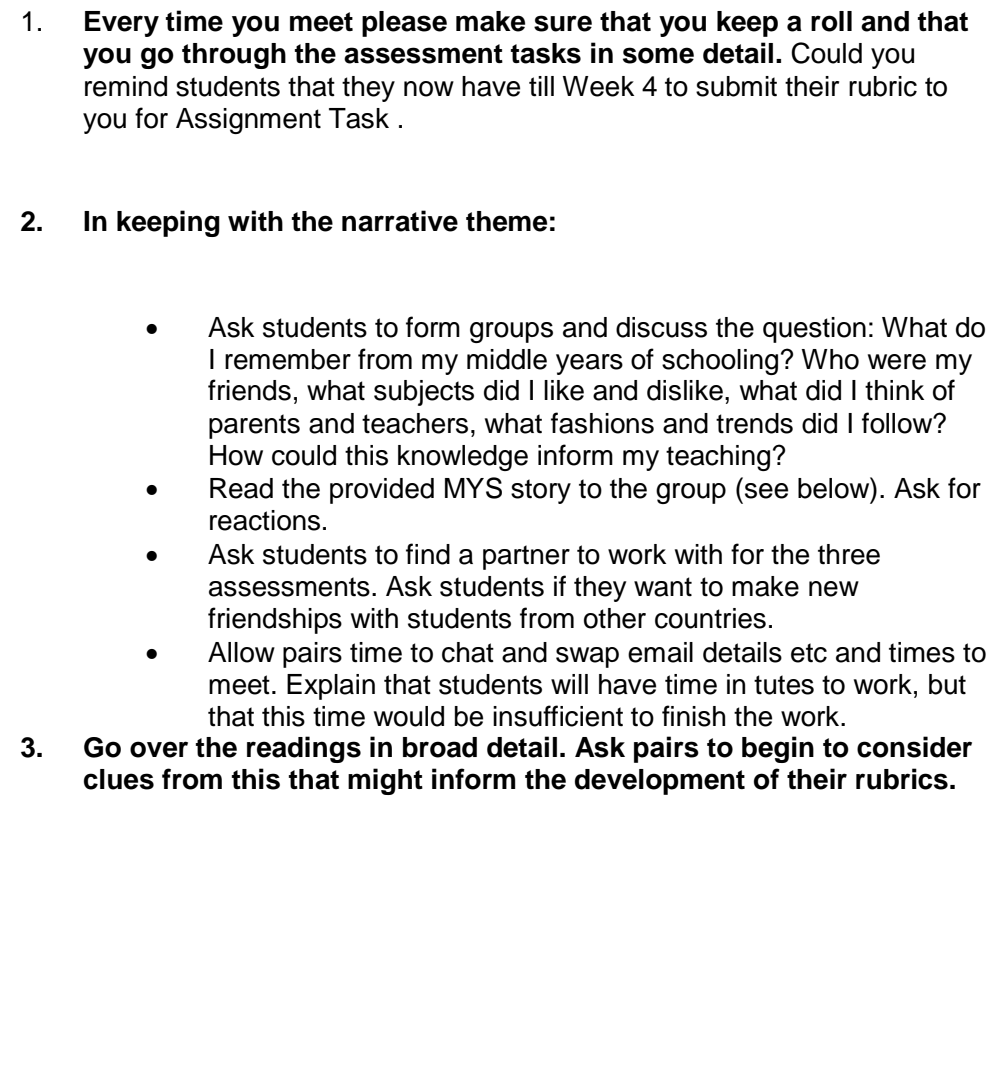 \\
\hline
\end{tabular}




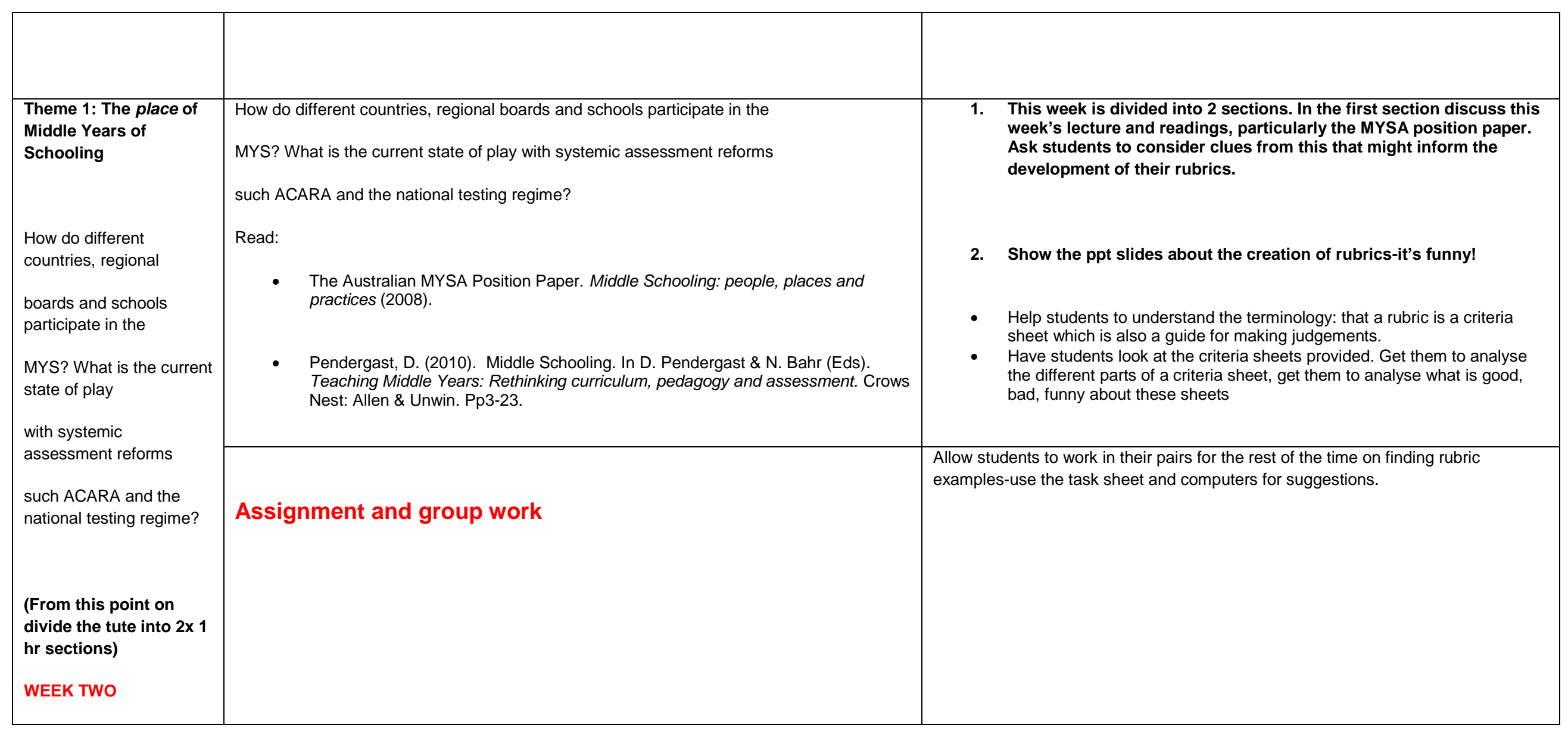




\begin{tabular}{|c|c|c|}
\hline \multirow[t]{2}{*}{$\begin{array}{l}\text { Theme } 2 \text { : Who are the } \\
\text { people in the Middle } \\
\text { Years of Schooling? }\end{array}$} & $\begin{array}{l}\text { Who are the young people in their middle years of schooling? } \\
\text { - How are they understood as learners in schools as sites for learning? } \\
\text { - With what issues and contexts must they deal? } \\
\text {-What resources can they access? } \\
\text { - Who can they be and not be? } \\
\text { - How are they conceptualised and organised in schools? } \\
\text { What does school mean to them? } \\
\text { Read Patel Stevens, L., Hunter, L. T., Pendergast, D., Carrington, V., Bahr, N., Kapitzke, } \\
\quad \text { C. and Mitchell, J. (2007). ReConceptualizing the possible narratives of } \\
\quad \text { Researcher } 34(1) .107-127 .\end{array}$ & $\begin{array}{l}\text { 1. This week we return to a discussion of the stories about people in } \\
\text { the middle years of schooling. The Patel article describes a number } \\
\text { of distinct stories and students should unpack these stories with } \\
\text { you. } \\
\text { 2. Group work: Copy the attached body shape onto A3 paper. Ask } \\
\text { students to form groups of four and flood the body outline with } \\
\text { answers to this question: Given the readings what would be a fair } \\
\text { and researched set of descriptors (adjectives) to describe students } \\
\text { in the MYS. Groups report back. } \\
\text { 3. And/or Complete the hot potato activity attached. }\end{array}$ \\
\hline & Assignment and group work & $\begin{array}{l}\text { Allow students time to evaluate a unit of work. I have provided one for you } \\
\text { below. Use the blank outline of a rubric for students to begin to fill in criteria } \\
\text { and standards for any unit of work. Allow students time to search for a unit of } \\
\text { their own and to play with their rubric. Students do not need to be in class } \\
\text { from this point on unless you have computers in your room. }\end{array}$ \\
\hline $\begin{array}{l}\text { Theme } 2 \text { : Who are the } \\
\text { people in the Middle } \\
\text { Years of Schooling? } \\
\text { WEEK FOUR }\end{array}$ & $\begin{array}{l}\text { This week we will look at students who are diverse within an already diverse range of students in } \\
\text { the MYS } \\
\text { Who are diverse young people in their middle years of schooling? } \\
\text { - How are they understood as learners in schools as sites for learning? } \\
\text {-With what issues and contexts must they deal? }\end{array}$ & $\begin{array}{l}\text { 1. This week concentrate on the diversity that exists within the cohort } \\
\text { of students in the MYS. Concentrate on the reading. The reading } \\
\text { talks about the third transition that children in these years may be } \\
\text { experiencing. The first transition is the transition to adulthood and } \\
\text { the second is the world's transition around them. Some students } \\
\text { have another transition. Ask students to compile a list of transitions } \\
\text { that students may be undergoing according to the reading. Ask } \\
\text { students to make a list of strategies that will help them. } \\
\text { 2. Break down some of the strategies to help students learn that are } \\
\text { listed in the article. }\end{array}$ \\
\hline
\end{tabular}




\begin{tabular}{|c|c|c|}
\hline & $\begin{array}{l}\text { - What resources can they access? } \\
\text { - Who can they be and not be? } \\
\text { - How are they conceptualised and organised in schools? } \\
\text { What does school mean to them? } \\
\text { Read; Garrick, B. and Keogh, J. (2010). Differentiated Learners in the Middle years. In } \\
\text { D.Pendergast and N. Bahr. Teaching middle years: Re-thinking curriculum, pedagogy and } \\
\text { assessment.Crows Nest: Allen \& Unwin, in press }\end{array}$ & \\
\hline & Assignment and group work & $\begin{array}{l}\text { Allow students time to work on their unit work and ask them to examine the } \\
\text { unit that they have chosen in light of the strategies mentioned in the article. } \\
\text { This will help them to make adaptations to their unit ready for the second } \\
\text { part of their assessment. }\end{array}$ \\
\hline $\begin{array}{l}\text { Theme Three: Practices } \\
\text { in the MYS } \\
\text { WEEK FIVE }\end{array}$ & $\begin{array}{l}\text { What is curriculum? Types of curriculum (integrated, negotiated, etc). How and by whom might } \\
\text { curriculum be constructed? How can curriculum be engaging for those participating in it? } \\
\text { What are the relationships between curriculum, pedagogy and assessment? } \\
\text { Reading: Shifting to more authentic language and literacy in the middle years, Komesaroff } \\
\text { and Morrison, (2002). } \\
\text { And } \\
\text { Stories of curriculum reform, Ch } \\
\text { 8, Ewing (2010) Ewing, R. (2009). Curriculum and assessment: A narrative } \\
\text { approach.Australia: Oxford University Press. Chapters } 7 \text { and } 8 .\end{array}$ & $\begin{array}{l}\text { 1. This week please concentrate on good curriculum stories such as } \\
\text { the Mt Alvernia example given in lectures and the Komesaroff and } \\
\text { Morrison example provided in readings. Both schools have students } \\
\text { who struggle with NAPLAN but have improved their results with a } \\
\text { negotiated curriculum and authentic assessment. } \\
\text { Complete the Mt Alvernia tute activity attached. This is an excellent } \\
\text { example of a fully negotiated curriculum process and is worth } \\
\text { considering in light of the national curriculum. }\end{array}$ \\
\hline
\end{tabular}




\begin{tabular}{|l|l|l|}
\hline & Assignment and group work & $\begin{array}{l}\text { Try to have students' rubrics back this week with suggestions of } \\
\text { improvement. Workshop what students should have had in their rubrics. (10 } \\
\text { signifying practices or versions of same). } \\
\text { Discuss authentic assessment and break down the Garrick paper with particular } \\
\text { reference to the use of the matrix in planning. } \\
\text { Have one group of students look at the unit in its entirety. Another group looks at the } \\
\text { authenticity of the unit, another group looks at the matrices used and so on....(They can } \\
\text { criticise the unit, but need to have reasons for the criticism.) }\end{array}$ \\
\hline & & $\begin{array}{l}\text { Focus on authentic tasks and collaborative, problem based learning. } \\
\text { Complete the negotiation worksheet entitled: Why did the ducks cross the road. }\end{array}$ \\
\hline
\end{tabular}

